\title{
Influencing Factors for the Growth of Informal Rental Housing in Yangon, Myanmar
}

\author{
Myint Naing \\ Department of Urban and Housing Development, Ministry of Construction, Yangon, Myanmar \\ Email: myintnaing.duhd@gmail.com
}

How to cite this paper: Naing, M. (2021). Influencing Factors for the Growth of Informal Rental Housing in Yangon, Myanmar. Current Urban Studies, 9, 40-65. https://doi.org/10.4236/cus.2021.91004

Received: January 17, 2021

Accepted: February 5, 2021

Published: February 8, 2021

Copyright $\odot 2021$ by author(s) and Scientific Research Publishing Inc. This work is licensed under the Creative Commons Attribution International License (CC BY 4.0).

http://creativecommons.org/licenses/by/4.0/

\begin{abstract}
Rental housing is an essential and the significant proportion of urban housing; it has been neglected by many governments due to various reasons. While $40 \%$ - $50 \%$ of urban population or 1.2 billion people reside in rented accommodation, a few governments around the world merely took rental housing as a policy matter during the last a few decades such as Colombia, South Africa and Indonesia. Rental housing especially informal rental housing is often labeled for bad reputation; a sizable proportion of the urban poor in Asia living in informal rental. Nowadays, Myanmar is one of the low-urbanized countries in South East Asia; the hint of rapid urbanization can be found in major cities especially in Yangon. Under the pressure of rapid urban growth, informal rental is the alternative residential solution for internal migrants and urban poor in Yangon. The main objective of this paper is exploring the influencing factors for the growth of informal rental housing in Yangon. A mixed research method, both qualitative and quantitive approaches, is applied to analyze data from both primary and secondary resources. Various forms of informal rental can be found in Yangon context, Multi-storeys Single-Roomed Rental (SRR) and Cell-Room Rental (CRR) are more prevalent. The influencing factors are the proximity of workplace, urban amenities, and relatives and friends; the affordability of cheap rental fee, low living cost and unaffordability of buying a house. Fear of being evicted in squatter living and rejection by squatter community also influences the growth of informal rental in Yangon. If government does not tackle the operative actions seriously, unprecedented urbanization rate of Yangon can surge in both the expansion of squatter pockets and the growth of informal rental housing.
\end{abstract}

\section{Keywords}

Cell-Room Rental (CRR), Informal Rental Housing, Internal Migrants, Multi-Storeys Single-Roomed Rental (SRR), Urban Rent Control Act 


\section{Introduction}

Rental housing is a stepping stone of residential solution for young urbanites and/or migrants and/or urban poor especially in the developing countries such as Myanmar. Rental housing is an integral part of the housing tenure and also a vital path to the stages of a migrant's upward mobility from squatter to homeownership (Kumar, 2016). Possibly, 40\% to 50\% of urban population lives in various kind of rental spectrum all over the world (Turner \& Malpezzi, 2003). Although a significant percentage of the population in every country resides in rental housing as formal and/or informal, many governments have neglected rental housing mainly for ideology reasons (UN-Habitat, 2003). Although rental housing especially informal rental was often labeled as bad reputation, it can encourage some benefits of urban system such as inhabiting urban sprawl and restraining slum expansion indirectly.

The Universal Declaration of Human Rights adopted by the United Nation General Assembly at its third session on December 10, 1948, stated that "all governments have an obligation in the housing sector, for instance, by creating ministries of housing or agencies that write the housing policies, enact the programs, plan the projects, and allocate the funds" (Ikhlas \& Shiki, 2020). Housing right in Myanmar is not apparently enshrined in the Constitution of the Republic of the Union of Myanmar like other developing countries such as Indonesia, Malaysia and South Africa (Ikhlas \& Shiki, 2020). Moreover, among the four political eras since getting independence in 1948, Myanmar Government had unfortunately adopted only one particular National Housing Policy under the Parliament Democracy regime (1948-1962) (Naing \& Nitivattananon, 2020a).

According to the 2014 Myanmar Population and Housing Census, merely $11.28 \%$ of the housing stock was formal housing, while the rest of them were informal and temporary housing such as huts (DoP, 2015). For urban area, standard housing is only $24.25 \%$ in Yangon and rest of the stock should be needed to refurbish or renovate. As the housing tenure, $64.5 \%$ of housing stock in Yangon was only homeownership and rest of them was tenants of any kinds of rental status (formal or informal). ADB mentioned that "if to meet the present and future need for formal housing, public and private sector together must deliver an average of one hundred thousand dwellings annually until 2030" (ADB, 2019). In reality, middle-income and urban poor cannot catch to hand to be homeowner because current formal housing production is round about ten thousand per year.

The main objective of this study is to analyze on the influencing factors for the growth of informal rental housing which is the newest form of informality in housing sector of Yangon. Moreover, it is studied on characteristics of informal rental, policy interventions and strategic implementations from international experiences; and typologies of informal rental including land lords' types and practices, socio-economics situation of tenants in Yangon. This scope of research for this study is on informal rental issues of Yangon as the business capital and the most populous city of Myanmar. Besides, the definition of the infor- 
mality is very widely depending on different agendas, this research focuses only into ignorance of minimum requirements for habitable standards and the legality of landlord-tenant rights and responsibilities.

\section{Literature Reviews}

Principally, housing policy for home-ownership scheme has been considered the betterment for both individual and community. Homeowner can have the merits for morale such as pride, happiness and stability, and the merits for socio-economic such as equity, security and financial benefits. Likewise, home-ownership scheme can have multiplier benefits for financial sector, building and construction sector, and manufacturing sector. Moreover, it can creates substantial job opportunities and supports for poverty alleviation (UN-Habitat, 2008; Peppercorn \& Taffin, 2013).

While many governments aggressively promoted homeownership with many reasons especially with political intention, notable numbers of people who live in Asian urban centers continue to rent rather than buy the house (UN-Habitat, 2008). Although; $40 \%-50 \%$ of urban population or 1.2 billion people live in rented accommodation or one kind of rental spectrum, a few governments have taken rental housing seriously as a policy matter during the last a few decades (UN-Habitat, 2003; Turner \& Malpezzi, 2003; Gilbert, 2015). Particularly, a significant proportion of the urban poor in Asia, are in formal rental. For instance; over half of low-income rental or a quarter of total rental housing stock are informal in India (Naik, 2015).

\subsection{Rental Housing}

While majority of people want to own their home, rental housing (whichever formal or informal) that is an important element of housing market and an essential proportion of housing spectrum especially in urban areas (UN-Habitat, 2008; Peppercorn \& Taffin, 2013). Root cause for renting is unaffordability of buying a house while they have other logical reasons such as mobility, flexibility in managing their household budgets, transitory periods of their lives, avoidance of long-term financial commitment and increase of their remittance (UN-Habitat, 2008; Peppercorn \& Taffin, 2013). Although rental housing practices suffer many bad reputations especially exploitation of landlordism and lower quality of life such as crowding, sub-standard housing and poor physical infrastructure, informal rented housing plays a vital role in many rapid growing cities in the global south (Scheba \& Turok, 2020).

On the third world, formal housing market and public housing programs cannot fulfil with the accelerating demand from low-income group especially in prime cities. Common phenomenon of formal housing shortage is formation and expansion of squatter in the developing countries, informal rental is as alternative choice of urban poor with many reasons especially the scarcity of well-located land parcels, rising of land values and threat of eviction. Informal 
rental is the last resort for migrants and urban poor; proliferation of informal rentals reflects the immense shortage of affordable housing in context of rapid urbanization mainly in Asia, Africa and Latin America. Learning from South Africa, the government can be strongly able to prevent land invasion, informal rental is the only option of shelter for urban poor (Scheba \& Turok, 2020).

Rental housing is a significant agenda for major cities especially recent urbanized cities of Asia, urban rented statistics are not easy to assess. Rental housing especially informal rental is often hard to distinguish rental from owner-occupied housing; it is dispersed all over the city; it is hard to tell landlords from their tenants, and both landlords and tenants often quietly keep their rental relationship. Generally, potential renters consider choosing where and wanting rent that based on many factors. Well-functioning rental housing market provides a variety of rental options at affordable rental fees and with access to work place. Particularly, tenant's choice can be influenced by basic factors as the quality and durability of the building materials, the level of maintenance, the level of crowding, access to jobs and public services, access to basic infrastructure, location and social support systems, tenant's mobility, tenant's income level, and tenant's stage in the life-cycle (UN-Habitat, 2008).

\subsection{Informal Rental Housing}

Potential tenant logically demand formal rental rather than informal. But, cultural norms, tax codes, socio-economic conditions and regulations often push formal rental housing into the informal sector. Informal rental practice is an evitable phenomenon and a vital role of housing market spectrum especially rapid urbanized cities of the third world. For instance; In Accra, and Bogota, tenants comprise over half of urban residents of low-income settlements. In Metro Manila, about $80 \%$ residents of informal settlement are tenants (Scheba \& Turok, 2020). Similarly, 25\% of India's housing stock is informal rentals (Naik, 2015). Although, informal rental has had many adverse effects such as overcrowding, social discontent, health and safety risks, and pressure on public infrastructure, it is uncontrollable issue for local authority in global south.

Ananya Roy as the famous urban planner mentions that root causes of informality in India's cities are not only "a failure of planning" but also "the idiom of urbanization". Moreover, she describes on informality as "state of deregulation in laws", "open-ended and subject to multiple interpretations and interests in usage of land", "practices of un-mapping" and "an instrument of both accumulation and authority" (Naik, 2015). On the third world; market liberalization, globalization and the reduced role of the state which can escalate the informality including informal rental.

Usually, research on housing informality have focused on slum and squatters especially issues on property titles, tenure secure, hard and soft infrastructure and so on (Naik, 2015). Research on informal rental began in late of $20^{\text {th }}$ Century and which has been attracted growing scholarly and policy interest (Amis, 1984). 
Nowadays, some governments promote the role of rental housing including informal as alternative solution of shelter issues for middle-income and urban poor.

Early type of rental housing is an informal subdivision of land-plot of small landlord such as backyard shack or backyard renting from South Africa (Gilbert, Mabin, Watson, \& McCarthy, 1997; Lemanski, 2009; Shapurjee \& Charlton, 2013). Firstly, subsistence landlords subdivide and rent out their property for sheer necessity to generate some income for basic household needs. Almost all of tenants built their houses and they were really renting only the space. Several studies of backyard rental in the early stage found that most landlords were not charging rent or trying to maximize their income.

Gradually, informal rental practices change into commercialization and rental income was the main motivation for renting out their backyard space, driven by the poverty and unemployment. Other types of informal rental practices have been introducing and emerging by the entrepreneur landlords with commercialization. For instance; some studies pointed out that most of residents in informal settlement at Nairobi are renters and the construction of informal buildings is indeed a lucrative business (Mwangi, 1997).

Although, informal rental is commonly unacceptable shelter from social aspect, Social Housing Foundation (South Africa) mentioned much merit can be obtained from informal rental (Carey, 2009). It is a significant, efficient, effective, functioning market that provides poor people with affordable accommodations. This housing segment provides a significant income for many poor households; more accommodation for urban poor; the opportunity to densify human settlements and leverage existing stock and infrastructure; better access to transport, work opportunities and services; and mixing to urban poor and the urban fabric.

\subsection{Typologies of Informal Rental Housing from International Experiences}

Generally, typologies of informal rental can be divided into five configurations as sub-divided rooms in inner city areas; rooms and flats in multi-storeys tenements; rooms in various low-income settlements; sub-let units on rented land and tenant-built units in the backyards of dwellings (Shapurjee \& Charlton, 2013). Prevalence of the various types of informal normally depends on size, rental rate, basic facilities (water, electricity, cooking place and toilet), location, and disregard of local authorities. Types of informal rental from international experiences are not too different and peculiarity is commonly based on scarcity of land, receiving the building materials, getting the public infrastructures, socio-economic situation of tenants, and cost and benefits of landlord. Similar circumstances of informal rental are generally narrow space, insufficient basic facilities, unlivable condition, health and safe risks, and unfair landlord-tenant relationship.

In South Africa, backyard renting was the only option during the 1970s and 
1980s because government had controlled strictly on land invasion. After demise of apartheid, ease of government control on informal settlements resulted on expansion of squatter settlements and increase of many types of informal rental. The boom in informal rental has had many adverse effects such as overcrowding, social discontent, health and safety risks and pressure on public infrastructure (Gulyani, 2008).

Noticeable types of informal rental in South Africa are backyard shack, onestorey micro-flat, two-storey micro-flat and boarding house (Scheba \& Turok, 2020). Boarding house was the new form by entrepreneurial landlords as the nature of landlordism. The prevalence of home owner and entrepreneurial landlords clearly demonstrates that social aspirations and associated conditions. Boarding house is a large building with multiple rental rooms (usually two to three storeys) as individual one room unit and sharing common facilities (such as bathroom, kitchen, toilet and living room) or self-contained unit with a small kitchenette and a toilet/shower. Typical drawing of a boarding house can be seen in Figure 1.

From India experience; four typologies of informal rental are mainly found at Gurgaon in National Capital Region (NCR). There are Jhuggis (Semi-permanent single-floor tenements), Permanent multi-storey pukka tenements, and Pukka rooms with share toilets and Pukka rooms with separate toilet. Among these four types, Jhuggis was commonly built by tenant or contractor and rest of them was constructed by landlord. Typical multi storey tenement-type rental housing can be illustrated in Figure 2.

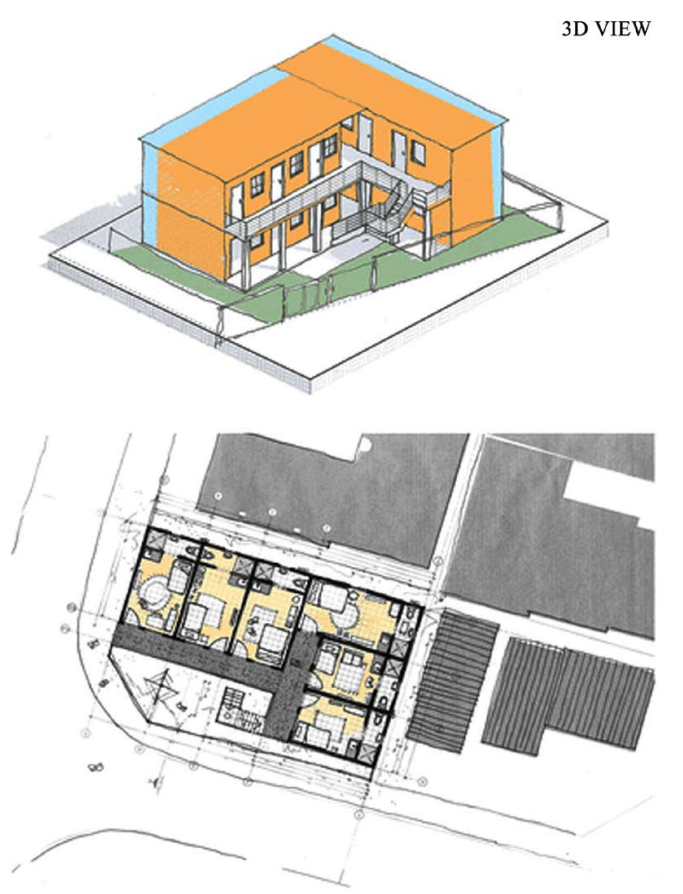

Figure 1. Architectural of boarding housing in South Africa. Source: Scheba \& Turok, (2020). 


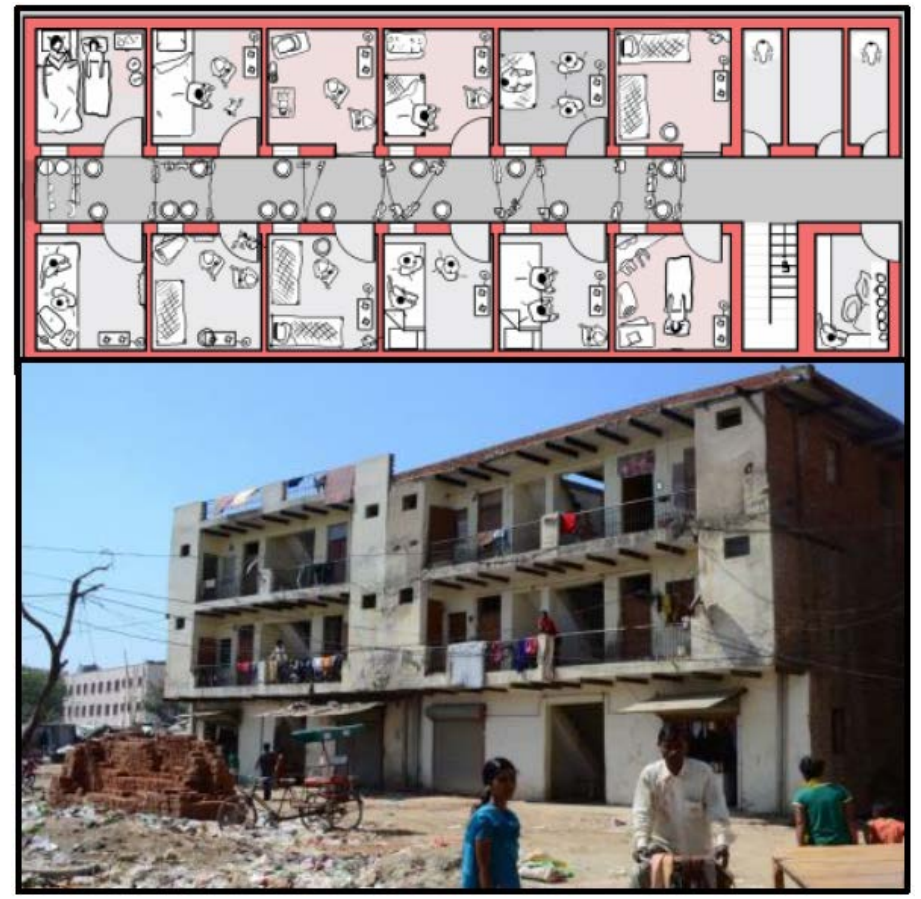

Figure 2. Plan and simple photo of tenement-type rental housing in India. Source: Naik (2015).

Remarkable rental housing can be seen in Kenya which was labeled as "Informal Modernism". Example of this informal modernism can be found in "Block 10" in the eastlands area of Nairobi (Anyamba, 2005). The developer constructed 8 - 10 storey single roomed apartment block on the small plot as the range between 40 - 50 feet by 60 - 100 feet without urban planning standard. Usages of ground floors are commonly commercial usages as shops, saloons, pubs and butcheries etc. Upper floors are intended for residential units of the potential renters. Each floor can have approximately 20 rooms with sharing 2 - 3 bathrooms and toilets. Therefore, while each floor can reside round about sixty persons, it gives a ratio of 20 people per toilet that is extremely above the recommended 5 - 6 persons per toilet. Terrible issue is that these buildings are without lifts as negligence of formal requirement as lifts to be installed in building of more than 5 floors. Informal modern block in Kenya can be stated in Figure 3.

\subsection{Policies and Implementation for Coping Informal Rental from International Experiences}

Along the $20^{\text {th }}$ Century; majority of governments from the developing countries have been pursuing the development of home-ownership as main housing policy which followed western models. However, some governments gradually accepted this policy only based on home-ownership program is weak. Therefore, a few of the governments from third world such as Colombia, South Africa and Indonesia, who started to recognize rental housing programs (both public and 


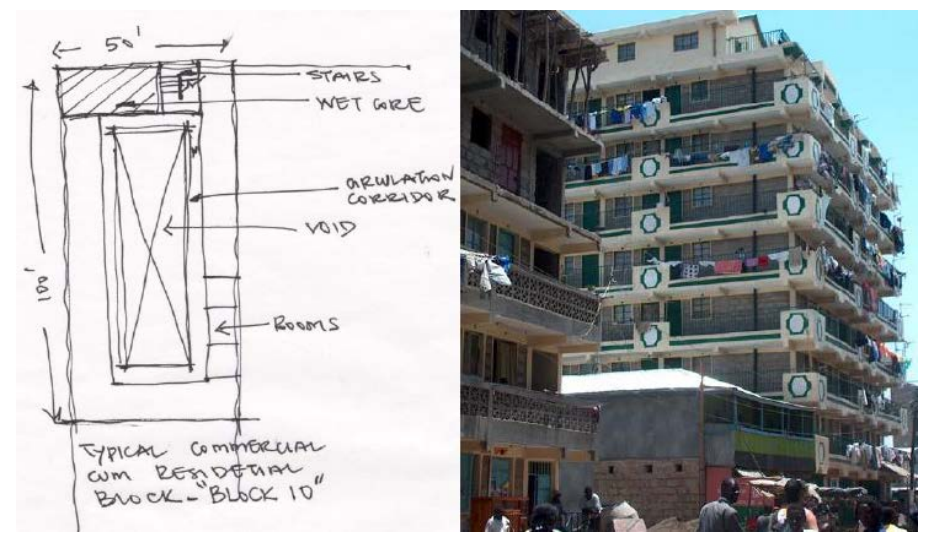

Figure 3. Plan and scene of modern block of informal rental in Kenya. Source: Anyamba, (2005).

private rental scheme) as alternative opportunity for improving the residential status of citizen especially urban poor (Watson \& McCarthy, 1997; Ballesteros, 2004).

UN Habitat mentioned that there are four major problems with rental housing in Asian Cities as 1) housing policies are often biased in favor of home owners and failure to take rental housing into account; 2) when rental housing conditions are poor, the problem is not usually with the rental arrangement itself; 3 ) rental housing is closely linked to the way a city's overall housing market functions; and 4) because so much of rental housing is informal and largely "invisible," a lot of it falls outside of the control of government rules and regulations (UN-Habitat, 2008). UN Habitat recommend 6 ways to promote rental housing in housing policies as 1) acknowledge and understand existing rental practices; 2) get rental housing on the larger urban policy agenda; 3) work out practical, flexible rental housing regulations; 4) ensure that rental housing arrangements are sustainable; 5) mobilize finance to improve and expand rental housing; and 6) large scale investment in rental housing.

On the other hand, as a notable policy recommendation from South Africa that the overriding goal of any informal rental policy must be to allow it to continue to apply this very important function of providing shelter the poorest (Watson, 2009). Mainly, this market segment is not only about the number, it is also about the affordability. For many urban poor, informal rental is all they can afford, or choose to afford (Carey, 2009). As the important feature of informal rental that does not exist in isolated practice from other housing segment because tenants can move up or down depend on income and preference as internal causes, and market situation and government intervention as external causes. They can move to slum and squatter or formal rental or owned-houses or public housing schemes even back to their native home.

SHF suggests that the basic idea of supporting the informal rental, as a way to significantly increase the supply of affordable rental accommodation and/or to uplift their inferior living condition. The solutions must be sought in introduc- 
ing minimum health and safety standards. These can build on the positive aspects and reduce the negative aspects (Carey, 2009). Positive aspects are to support more sustainable land and infrastructure use, to promote urban integration, to provide a very important livelihoods strategy to support economic activity for the poor and to provide an affordable accommodation solution for a growing market. On the other hand, negative aspects are exploitation, bad condition of health and safety issues, the invisible nature of tenants and the overloading of urban infrastructure and services.

Strategies to support and encourage or cope with informal rental housing can be mainly divided into two sets as supply-side strategies and demand-side strategies, and other strategies related with legal, planning and design, or regulatory (Watson, 2009). The main approaches for supply-side strategies are; capital subsidies or loans, tax incentives, urban investment zone, availability of micro-finance, relaxing and revising building and planning controls, design of new areas to facilitate informal rental, and state or NGO-initiated emergency or temporary shelter. Likewise, the main demand-side strategies are; subsidies paid to households, free or subsidized building materials for renters, rent pooling, rent control, state provision of rental housing or spaces, public acceptance of informal settlements, land sharing, leaseholds in informal settlement upgrade, and communal land arrangements and community land trusts.

The rental housing market development is one of the important agenda in urbanization, because the rapid urban growth through both natural increase and migration has strengthened to create a balance of advantage between ownership and renting (Ballesteros, 2004). In Philippine, Ballesteros suggested that government should encourage small landlords to provide more and better rental accommodation through; 1) building rental incentives into upgrading programs; 2) provide micro credit; 3) create appropriate planning and rental regulations in informal settlements; and 4) provide incentives to investments in low cost renting. Moreover, they should promote public rental and apply lease-to-own scheme as an alternative solution. To sum up, three basic ideology themes for informal rental housing policy should focus on Densification, Health and Safety, and Land \& Tenure Rights (Carey, 2009).

\section{Research Methodology}

In this study; mixed research design is mainly applied, collecting both primary and secondary data resources with qualitative and quantitative approaches for data analysis. Characteristics of informal rental, policy interventions and strategic implementations were studied from mixed approach with secondary data from literature reviews and documents from concerned organizations, and primary data from FGDs, KII (Key Informants Interview) and survey questionnaires. Typologies of informal rental housing were studied through combination of secondary data sources from literature reviews and governmental documents and primary data from site visits and Focus Group Discussion (FGD). As a key 
part, influencing factors of informal rental housing as newest formation of informality in shelter will be analyzed from data analysis results of questionnaire survey.

\subsection{Study Area}

Yangon, the research area, is situated on the part of Irrawaddy delta which is the longest and the main arterial river of Myanmar Civilization (Kyaing, 2014). Besides, Yangon is the most populous city and business capital of Myanmar and its population was five times more than the second largest city of Myanmar called Mandalay (DoP, 2015). This city has accepted 5.16 million (2014) which is one-tenth of Myanmar total population, one-third of urban population and it produces about a quarter of national GDP. Urban growth of Yangon is the highest among all cities and towns and it will be mega city during next two or three decades. In term of rental status (formal and informal), 485,474 units (30.6\%) were rental housing (including public, private and employer's rental) in 2014 (DoP, 2015). For informal rental, two types of informal are very prevalent in current as Multi-Storeys Single-Roomed Rental (SRR) (suburban areas) and Cell-Rental Rooms in Apartment (CRR) (inner city). Most prevalent townships of informal rental can be stated in Figure 4.

\subsection{Data Collection and Analysis}

The collection of data can be divided mainly into two parts as secondary data from literature reviews and documents from concerned governmental organizations especially General Administration Department (GAD) and Department of

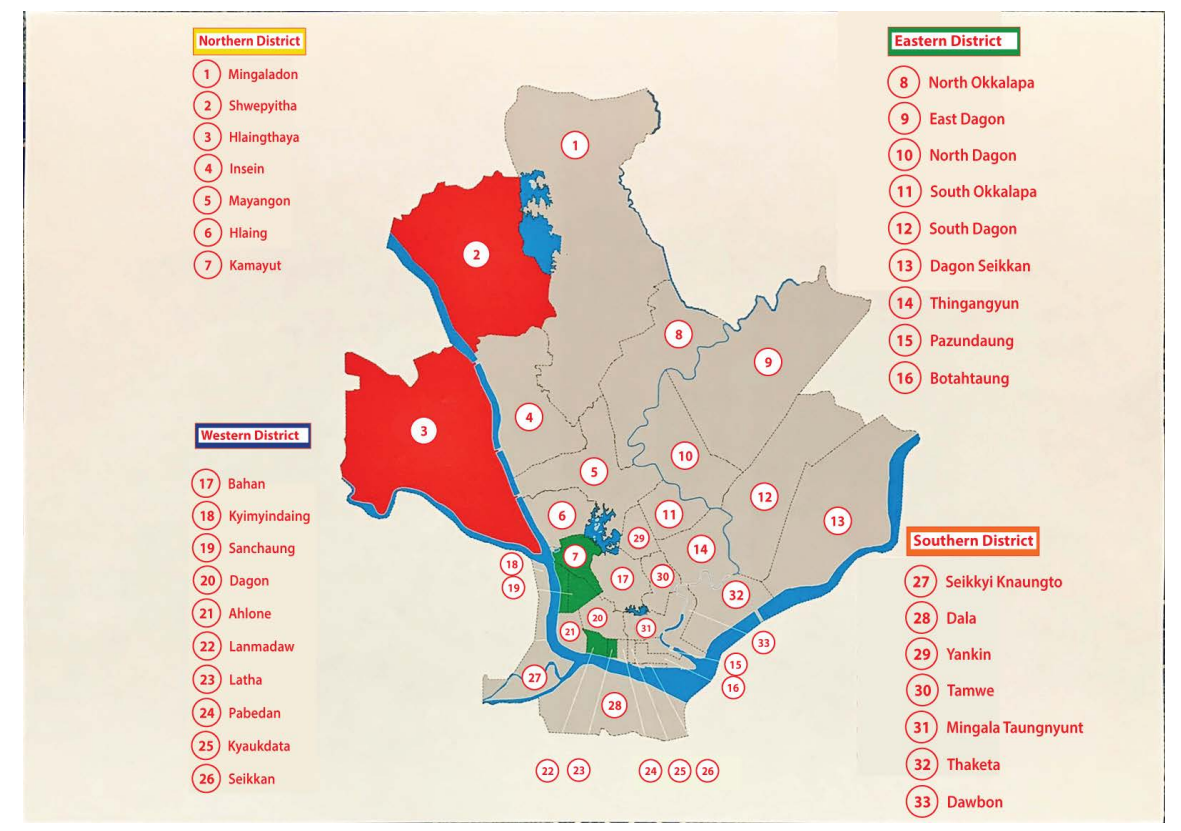

Figure 4. Map for most prevalent townships of informal rental in Yangon. Source: Author (2020). 
Urban and Housing Development (DUHD) and primary data from Key Informant Interview (KII), Focus Group Discussions (FGDs) and questionnaire survey. Data for Characteristics of informal rental, policy interventions and strategic implementations are examined through the methods of historical reviews and literature reviews, and collecting secondary data from documents of concerned organizations and primary data from site visits, KII and FGDs. Typologies of informal rental housing are compared from literature reviews, and site visits and FGDs. Influencing factors of informal rental housing as newest formation in Yangon are conducted mainly through questionnaire survey which was based on the empirical research from Swaziland (Matsebula, 2012).

Six interviewees as real estate agents are conducted for KII and twelve interviewees (each six lessors of SRR and CRR) were part of FGDs. The duration of a KII interview and two FGDs took around two hours per section. Participants from KII were the executive committee members of Myanmar Real Estate Services Association, and among them four are elderly and two are mid-age senior real estate agents. Major topics of KII are historical rental practices, socio-economic conditions of tenants, and trend of rental practices under successive political eras. Among FGD participants, two from CRR are female landlords and rest of them are male land lords. Regarding age concerns, SRR owners are generally mid-age but older than CRR landlords. Key topics of FGDs are business model of informal rental, operational issues, behavior of tenants and disputes between landlord and tenant.

124 respondents of informal rental are current tenants of SRR from Hlainethaya, and CRR from Lanmadaw which are most Influent Township of informal rental in Yangon as of now. The sampling method is based on stratified two-stage cluster sampling method to cover the total SRR and CRR rental practices of these two townships. As a first stage, six wards from Hlaingthaya and 6 streets from Lanmadaw are selected by probability proportional to size sampling. As a second stage, two eligible tenants from 5 landlords in each ward and street are selected as respondents by random selection with right hand rule.

Trend analysis is applied on the typologies of informal rental of Yangon. Likewise, narrative analysis through KII and FDGs were transcribed on types and practices of landlords and socio-economic situation of tenants. SPSS is used as main statistical tool for exploring the influencing factors of the growth of informal rental in Yangon as key findings of this research.

\section{Rental Housing Experiences in Yangon}

Rental Housing in Yangon is an old practice since British Colony era when it was erected after Second Anglo-Burman War in 1952. Mainly, Indian landlords had introduced rental housing intended to Indian migrants for commercialization during 1870s. Rental housing was rapidly familiarized among Indian Migrants due to rapid labor import for rice production. During the first phase as the Open Frontier (1870-1890) of three prominent phases in the growth of the 
rice industry, the flood of Indian Migrants were imported to Myanmar which could increase rental housing especially colie-barracks (informal rental) in Yangon (Chaturvedi, 2015). For instance; population percentage changes between Indian and Burman at the End of $19^{\text {th }}$ Century as $47 \%$ \& $46 \%$ (1881), $48 \%$ \& $40 \%$ (1891) and 48\% \& 33\% (1901) (Pearn, 1939). About rental housing, Pearn (1939) mentioned in his book that Municipal Committee instructed "all lodging houses to be registered, but no restriction had been placed upon the number of occupants of such establishments" due to public health (Pearn, 1939).

After independence in 1948, Yangon population was rapidly grown with internal migrants especially victims of the civil war. Housing shortage and housing problems including slum formation and rental issue were visible urban challenges, and government had recognized and committed to solve by setting it as a prioritized political agenda (Naing \& Nitivattananon, 2020b). They had strongly attempted to provide housing for people, set up a specific National Housing Policy (NHP) and delivered public rental housing scheme under the "Pyidawtha Plan" (Naing \& Nitivattananon, 2020a). During that period, government had provided public rental housing (6601) dwellings for low-income people during 1950s. On the other hand, squatter formation was the main solution of urban poor for shelter and they erected 56 ubiquitous squatter pockets all-over the city. The government built 3 new towns for squatter clearance and provided 32,866 land plots for them (Naing \& Nitivattananon, 2020b).

After the seizure of power by military in 1962, public rental housing scheme was gradually faded away. Socialist Government reduced public housing schemes and focused on only government staff housing for government employees and labor class with socialist ideology. Likewise, private formal rental businesses were also faded out due to urban rent control act and eliminating of the private sector role due to socialist ideology. Besides, demand side of rental had similarly decreased by low urban growth rate of Yangon. There were many reasons for low migration-in as low job creation during economic down time and difficulties for migrants by commodity ration book system of cooperative under Socialist regime. Therefore, rental practice was merely, petty landlord commonly divided their house and rented out to relatives and friends. Sometime, house owner shared rooms or ground floor or upper floor of traditional two storey wooden house for renter.

Under the military ruling (1988-2011), rental housing practices had been gradually familiarized by growth of rental demand. Military rulers stopped practicing Socialist Economy, recognized Market Economy, and promoted Private Sector Development. Migration rate was suddenly grown in Yangon during these two decades with liberalization and promoting of industrialization. This migration rate mainly caused by urban socio-economic pull factor was compared in Figure 5 by each decade. That rental practice was quasi-formal rental because landlord did not want to follow the enforcement of the Urban Rent Control Act (1960) Myanmar and to avoid taxation. Although, their apartments 


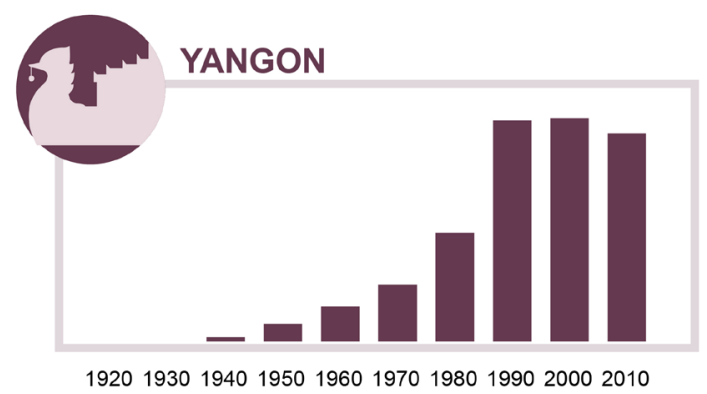

Figure 5. Percentage of identified migrants within each decade in Yangon. Source: (O’Connor, 2020).

or houses commonly standard housing, rental practice was informal without register deed. Moreover, least-term was usually less than one year due to limitation of the Urban Rent Control Act (1960) Myanmar.

\subsection{The Urban Rent Control Act (1960)}

The imbalance of supply and demand due to war, depression, earthquake, fire, plague or some other vagary of history can upset the normal state of affair which led to emerging of legal framework for rent control (Willis, 1950). Rent control spectrum is generally a controversial agenda and it is intended to social benefits and political agenda. However, rent control can occur negative impact for economic as distortion for supply-side. Therefore, principles of rent control gradually change in line with market economic ideology as three generations as "First generation" (control of rent levels), 'Second generation' (control of rent increases within and between tenancies) and 'Third generation' (control of rent increases within tenancies) (LSE, 2018).

After independence in 1948; the first Myanmar government encouraged housing agenda and founded "National Housing Town and Country Development Board" for uplifting on the living standard of citizen. Urban Rent Control act was initially enacted under British Ruling in 1946 because immense housing shortage had been facing with heavy bombardment by Second World War (WWII). Furthermore, the housing situation was worsening after WWII because civil wars continuously happening between government and various armed groups with ideology conflicts in the whole country and was unstoppable ever since.

Therefore, government amended and enacted the Urban Rent Control Act in 1960 and assigned to Department of General Administration (GAD) as a focal department. Although its responsibility was transferred to Housing Department (HD) in 1974, but retransferred to GAD in 1989 (HD, 1989). It is the first generation practice and strongly restricted rent level to prevent exploitation by landlord. But, successive government could not modify on better regulation as second or third generation. Moreover, procedure for eviction of bad tenant is very difficult and court procedure is also too long as many years. Gradually, private formal rental practice has been diminishing and pushing to informal rental 
because of this unjustifiable act.

\subsection{Causes of Failure of Private Formal Rental Housing}

Major reasons for failure of private formal rental are legal constraint as Urban Rent Control Act and weak private sector as long elimination under Socialist era. Although, formal rental especially commercial rental practices were very familiar by Indian landlords under the British capitalism, Parliament Democracy Government (1948-1962) had tried to control tightly with the Urban Rent Control Act due to immense housing shortage. Finally, private formal rental were totally eradicated under the Socialist Era (1962-1988) because of ideological conflict.

Under the Military ruling (1988-2011), although private formal rental had tried to introduce in accordance with market oriented economy, it could not be matured with many reasons especially legal constraints. Limitation of the Urban Rent Control Act is the main burden for exercising on formal rental practices. Moreover, eviction of bad tenant is very difficult under outdated and outmoded common law system.

Complexity of government procedure and uncertainty of government regulations are other key issues for potential commercial landlords in order to transform rental housing into profitable business setting. Another main reason was instability of economy under the Military ruling. Economic stagnation and instability of economy commonly attract short-term investment for potential investors. Generally, the barriers for investors to investment in formal rental business are low-profit margin and long term ROI (Return on Investments) as over 8-12 years. Moreover, landlord-tenant relationship is very problematic social interaction and lack of particular dispute resolutions is also frustrating for them.

\section{Demand and Growth of Informal Rental Housing in Yangon}

While Myanmar is low-urbanized country in South East Asia, hint of the rapid urbanization can be seen in major cities especially Yangon. Root cause of rapid urbanization in Myanmar is change of economic pattern from agriculture and natural resource based to industrial and services based economy. Moreover, other causes have been fueling the internal migration such as instability of agriculture sector with climate change, natural disasters such as Cyclone Nargis, and insurgency of remote areas. Yangon population was increased about hundred thousand annually and it had increased twofold during last three decades as 2.51 million (1983) to 5.16 million (2014) (Naing \& Nitivattananon, 2020a). Some scholar guess that Yangon will be mega city during two to three decades and government should consider how to encounter the urban challenges including housing shortage.

Under a long-isolated period over five decades (1962-2011), urban housing has not matured due to the underdeveloped nation, low population density combined with a huge land area, a greater ratio of rural to urban population 
(70:30), an abundance of natural building materials for informal housing, and incapacity of private house-builders (DUHD, 2012). About the current housing situation, a quarter of housing stock is only standard housing and the remaining is needed to refurbish and renovate.

Yangon housing market is a poor-functioning market with fragile key players as government, financial institutions, and housing suppliers (Naing \& Nitivattananon, 2020a). It is facing tremendous standard housing shortage with the insufficient supply by public and private sector. In current, formal housing supply can deliver one-third of annual demand and informal housing (slums, squatters and informal rental) has been substituted for housing shortage. For instance; registered squatter population was about nearly half million in 2014 and UN-Habitat estimated that round about one million population reside in informal housing as one-fifth of total population.

\section{Current Typologies of Informal Rental Housing}

According to the international experiences, typologies of informal rental can be categorized mainly into five configurations as stated in sub Chapter 2.3 (Shapurjee \& Charlton, 2013). It was pointed out that informal rental form, extent and nature (type of unit, housing quality, infrastructure levels, rents and tenure security) are shaped by the dynamics of the sub market (Desai and Mahadevia, 2014). Besides, settlement-specific processes and characteristics (such as settlement formation processes, topography, community mobilization, political patronage and location) and some owner-specific factors (such as plot/dwelling size, economic capacity and priorities) can effect on informal rental supply.

Unfortunately, all kind of informal rental can be found in Yangon and two types of informal are popular in current. There are multi-storeys Single-Roomed Rental (SRR) and Cell-Rental Rooms (CRR) in apartment among other typologies. Other types of informal rental can be found such as sub-let units on backyard, tenant-built units on private owned land, inform rental in squatter settlement. Moreover, pool-renting an apartment is also popular in inner city as another kind of invisible informal rental in Yangon.

\subsection{Multi-Storeys Single-Roomed Rental (SRR)}

Multi-storeys Single-Roomed Rental (SRR) which was started in Hlainethaya, the most populous township of Yangon during 2000s. Entrepreneur landlords had constructed and introduced two-storeys single-roomed terrace building and rent out to potential tenants mainly migrants. Typical size of land plot is 40 feet (wide) to 60 feet (long) and building size is generally 20 feet to 50 feet. Building was commonly constructed as traditional construction by local skill labor without supervision of professionals. Besides, it usually does not follow building standards and codes. Room size is generally 10 feet to 10 feet (100 square feet which equivalent to 9.29 square meter), and bathroom and toilet are common used. 3D illustrative drawing of SRR can be seen in Figure 6 . 


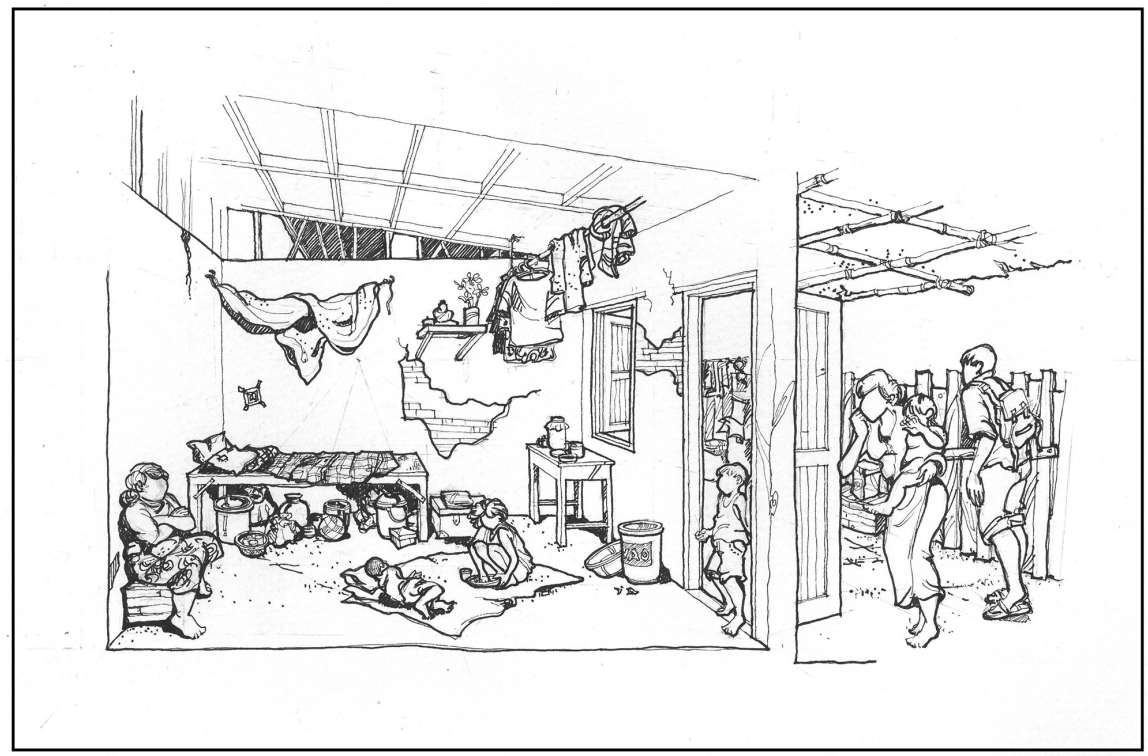

Figure 6. 3D illustrative drawing of single-roomed rental. Source: (Author, 2020).

Some landlords have modified and extended to three or four storeys huge buildings on combination of many plots as 2 plots $(80 \mathrm{ft} \times 60 \mathrm{ft}), 3$ plots $(120 \mathrm{ft} \times$ $60 \mathrm{ft})$, and 4 plots $(80 \mathrm{ft} \times 120 \mathrm{ft})$. These huge buildings can accept more tenants as 60 rooms to 120 rooms and some landlords commercially operate up to ten buildings and above. Although potential tenants are single or couple without children in introduction stage and family with 2 to 3 children gradually rent and live the terrible and crowded room. Photos of SRR can be seen in Figure 7.

This practice is gradually spread out the whole Hlainethaya and other townships of Yangon suburban area especially Shwepyitha. According to the GAD data in 2019, SRR buildings could be counted over six thousand buildings in Hlainethaya alone. Therefore, SRR units can be estimated between 80,000 to 120,000 units, population of SRR can be guessed round about 150,000 populations which can be compared to 120,736 as Hlaingthaya's registered squatter population (2017). List SRR buildings by each ward in Hlaingthaya Township can be stated in Table 1 .

\subsection{Cell-Rental Rooms in Apartment (CRR)}

Cell-Rental Rooms in apartment $(C R R)$ is the other popular informal rental type especially in inner city area because of its location. Private hostel practice is old practice in Kamayut Township which is situated near Yangon University. Under the Socialist's era (1962-1988), homeowners from Kamayut had usually rented to University students and short-term migrants who moved to Yangon for attending for vocational training and other purposes. In 2000s, homeowners especially apartment owners started to accept all potential tenants especially single person as informal rental as hostel. Kamayut is vitally situated as the junction of urban transport network and commuters can have good access for travelling 


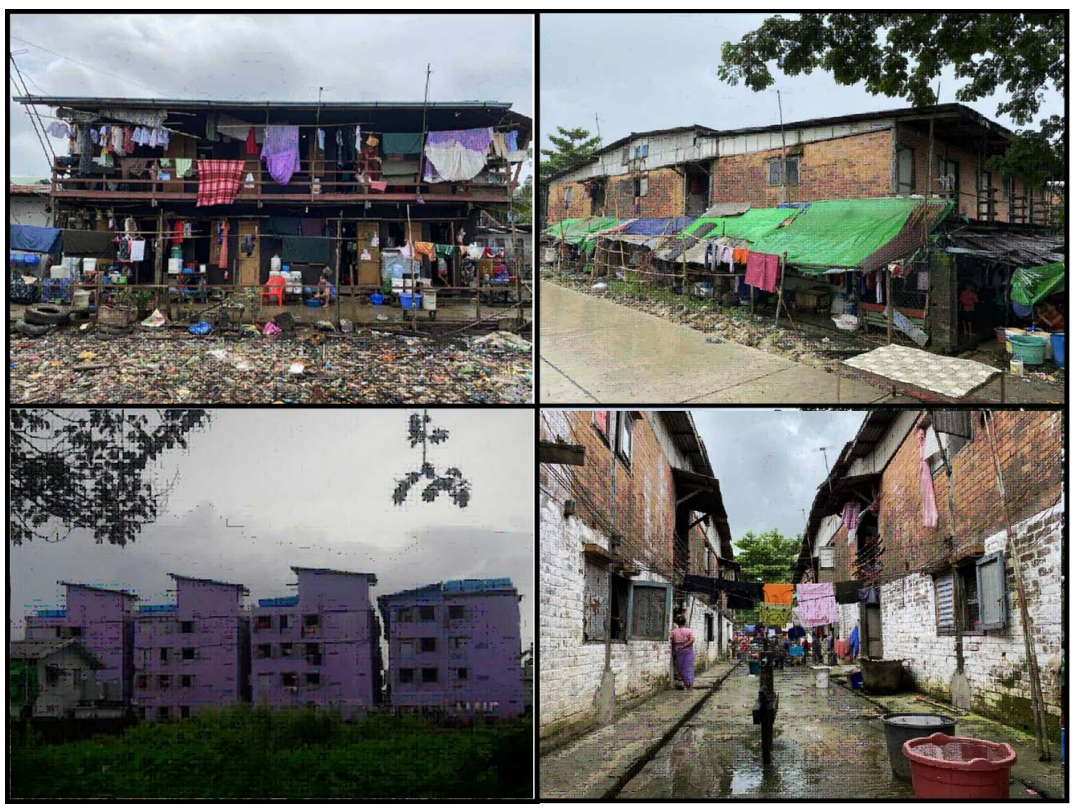

Figure 7. Photos of example SRR buildings in Hlainethaya. Source: Author (2020).

Table 1. List of SRR buildings by ward in Hlaingthaya Township.

\begin{tabular}{cccccc}
\hline No & Ward & Building Unit & No & Ward & Building Unit \\
\hline 1 & One & 370 & 10 & Eleven & 150 \\
2 & Two & 120 & 11 & Thirteen & 139 \\
3 & Three & 281 & 12 & Fifteen & 137 \\
4 & Four & 20 & 13 & Twenty & 1000 \\
5 & Five & 430 & 14 & Shan Chaung & 193 \\
6 & Six & 530 & 15 & Ye Okkan & 600 \\
7 & Seven & 820 & 16 & Nyaung Ywa \& Di Su & 460 \\
8 & Eight & 68 & 17 & Shwe Lin Ban & 395 \\
9 & Nine & 150 & 18 & Ah Twin Ba Dan & 550 \\
& & & Total & & 6413 \\
\hline
\end{tabular}

Source: GAD (2019) (Data from Office of Township Administer, GAD).

the whole Yangon city. Therefore, this kind of informal rental can attract entry level staffs of private companies, employees from service sector, and short-term migrants especially single person during their transit period.

Gradually, entrepreneur apartment owners constructed temporally cell-rental rooms and rent out potential tenants as a commercial business. Typical hall type apartment sizes in Yangon are $25 \mathrm{ft} \times 60 \mathrm{ft}$ or $12.5 \mathrm{ft} \times 60 \mathrm{ft}$ depend on land plot size. Generally, apartment $(12.5 \mathrm{ft} \times 60 \mathrm{ft})$ are parted to cell rooms 4 feet for single bed or 8 - 10 feet for twin bed with plywood or other boards. Cooking is normally prohibited and bathroom and toilet is provided as common facilities. 3D illustrative drawing of CRR in apartment can be seen in Figure 8. 


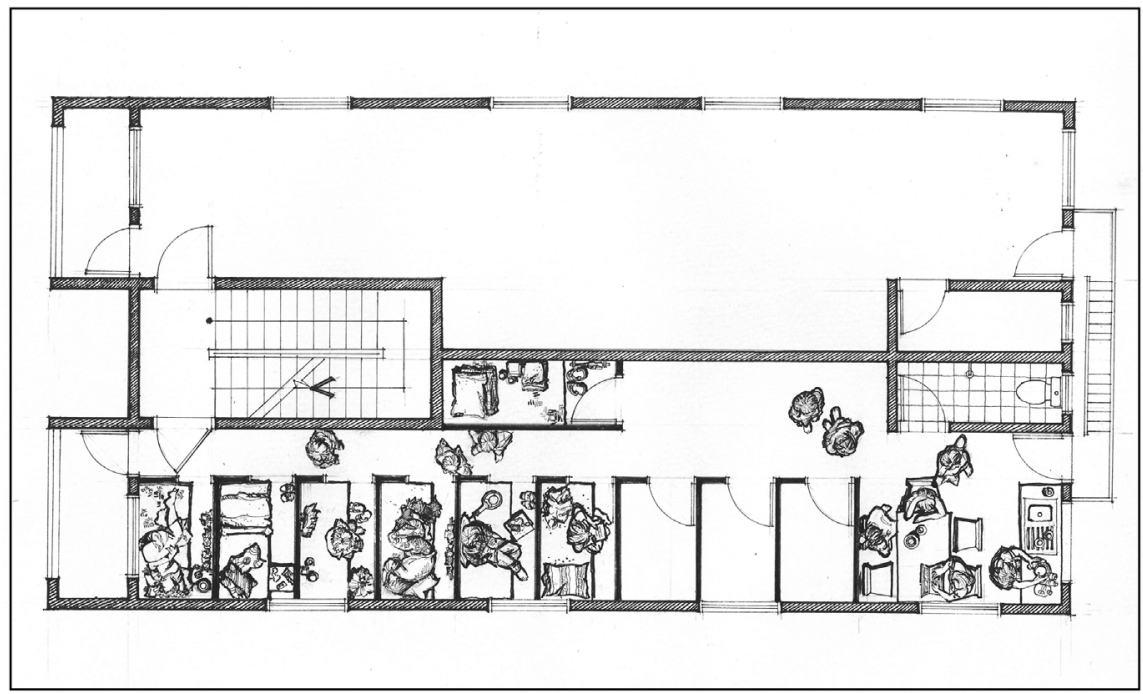

Figure 8. 3D illustrative drawing of cell-rental room. Source: (Author, 2020).

CRR type is generally spread out on junction townships along the road network of inner city especially Lanmadaw, Latha, Sanchaung, and Kamayut. This practice is expected to rise in the future because of worsening traffic condition. As a finding of FGD, 122 apartments have converted to CRR in Ward-No (3), Lanmadaw alone as $20 \%$ of total apartments. As converting residential apartment to CRR is a common practice in these townships, it is hard to obtain information from reluctant owners. Owners of the converted apartments are not willing to let local authorities to regulate and monitor their practice.

\subsection{Other Types of Informal Rental}

Although CRR and SRR are most popular types of informal rental, other types can be found in Yangon. There are sub-let rental units on backyard, informal rental in squatter and tenant-built rental. These forms can be found commonly in outskirt of the city and some are built on agriculture lands in adjacent city boundaries. Sub-let rental units are mainly found in old satellite towns (Thakayta, North Okkalapa and South Okkalapa which were erected in 1960s). Typical land plots provided by Government schemes are 40 feet (wide) to 60 feet (long) or 20 feet (wide) to 60 feet (long). Some land owners informally divide as 20 feet to 20 feet and rent out to potential tenants. In this type, building is constructed by land-owner or tenant depending on agreement. Most of buildings are semi-permanents and majority of tenants are relatives or friends or from same native towns. This type is commonly a little expensive because of location and wider usage area.

Practice of informal rental in squatter pockets can be found in 6 new satellite towns (Hlainethaya, Shwepyitha, and four Dagon Myothits) which were erected by Military government in 1990s. According to the data of Yangon Region Government, registered squatter pollution of these 6 townships was 265,890 as $56 \%$ of total squatter population (Naing \& Nitivattananon, 2020b). Some of the 
squatting is commercial squatting and they build extra hut and rent out to new migrants. For instance; survey result by UN Habitat (Myanmar) pointed out that $14 \%$ of respondents in Hlainethaya were renting status in squatter (UN-Habitat Myanmar, 2018). Majority of informal rental houses are merely temporary shelter as huts and rental fee is generally between 25 USD to 50 USD per month depend on location and size. Tenant-built rental is mostly applied on agriculture land of adjacent of urban area. Land owner rent out a piece of farm and tenant construct owned house by self. Therefore, rental fee is charged for only land use right. It is not too popular because potential tenant must be incurred construction cost and lack of essential services such as potable water, electricity and so on.

\section{Influencing Factors for the Growth of Informal Rental Housing}

Many researches explored that demand is a key driven force for the growth of informal rental housing which is rooted by three fundamental aspects as the affordability, the proximity and the flexibility (Carey, 2009; Gokhale, 2016). Informal rental housing is prevalent among the potential tenants due to aforementioned attributes as the affordability in rental fee with the proximity of livelihood opportunities and the flexibility to survive in urban community. According to the empirical survey results, influencing factors for the growth of informal rental housing of current Yangon is closely related to these three fundamental aspects.

\subsection{Profile of Landlords and Tenants in SRR and CRR}

Whereas landlord and tenant are key players of informal rental housing, business practices and socio-economic conditions can be varied in the different types of informal rental in Yangon context especially between SRR and CRR. While majority of CRR landlords are petty landlords, SRR practice is lucrative business among potential entrepreneurs and its profit become primary income for many SRR landlords. For instance; among 122 CRR apartments in Ward No-3 (Lanmadaw Township), only 3 CRR owners can operate commercially very well and most owners could not depend as primary income on this rental business because of low investment and revenue ratio.

\subsubsection{Landlords' Types and Practices}

While SRR and CRR are the more prevalent types of informal rental in Yangon, landlords' types and practices are roughly differs. Majority of the SRR landlords are migrant entrepreneurs, and the most CRR landlords are native and petty landlords. Because; SRR informal rental is lucrative business and return of investment is more than CRR. Due to the location and land price are totally different between inner city and suburban and building cost are also different between a standard apartment and a sub-standard building, a lettable floor area of SRR is commonly two times larger than CRR when investment amount and rental rate are the same. On the other hand, as the business set-up and closed down 
period for CRR businesses took around one month i.e.(Demolition of temporary partition), SRR practice take time at least 6 months for set-up and the rigid form of building (intended on informal rental only) which is very difficult to transform other usages.

Similarly, potential tenants are different as SRR target mainly on migrant family from industrial sector and transient labors for long term lease and CRR focus on single person especially employees from services sector. Occupancy rate of CRR is not stable which can be as low as $40 \%-60 \%$ and CRR tenants always find better place (especially sharing rental apartment with relatives or friends or coworkers), because of inconvenient of very narrow space and privacy. Both SRR and CRR have only verbal agreement between landlord-tenant relationship and they don't want to have registration and licensing officially. Commonly, rental fee collection is monthly basic without deposit that is affordable and flexible for tenant. It can be compared with formal rental practice as annual payment in bulk because of restriction of the Urban Rental Control Act (1960) Myanmar.

Contrariwise, majority of landlords want to avoid taxation and they want to escape from governing and monitoring by local authorities. As the noteworthy fact, all of landlords of SRR and CRR have lack of knowledge and awareness on rules and regulations related to rental services and they don't recognize their lawless manners of informal rental practices. For instance; almost no one recognizes and follows the Urban Rental Control Act (1960) Myanmar and they are not aware of housing standard of Myanmar National Building Code which mentioned floor area/person should be 100 square feet and minimum room size must be 60 square feet (MNBC, 2020). Most of SRR and CRR are neglectful to not only habitable floor area but also other basic services as potable water, electricity, toilet, kitchen, solid waste management; and the social services as parlor, worship and others.

\subsubsection{Socio-Economic Situation of Tenants of SRR and CRR}

Although majority of tenants are internal migrants, socio-economic conditions are very different in SRR and CRR. 117 respondents out of 124 are migrants across the country, mainly from Arrawaddy, Mgaway and Bago Regions as 43\%, $14 \%$ and $14 \%$ of respondents respectively. Motive for internal migration of these social groups are rooted in socio-economic push and pull factors primarily to have job opportunities, to get higher-income and to create a better life as pull factors and less job opportunities in native areas as push factor. Peculiarly, while insurgency is one of the main causes of internal displace persons (IDPs) in remote regions especially Kachin, Kayin, Shan and Rakhine State; only 1 respondent answered that the cause of civil war as main reason for him. Migration durations are varied among respondents which can be compared the largest proportion as $40 \%$ have been above 10 years, $23 \%$ have been 5 - 10 years, and rests of them have been below 5 years.

In term of education status, only $23 \%$ of respondents are graduated and rest of 
them as $77 \%$ are basic education as primary and secondary education. Among them, tenants from CRR of inner city are more educated as 26 out of 28 graduated tenants. Regarding the occupation; majority of SRR's tenants as $54 \%$ are from industrial sector and 56\% of CRR's tenants are from services sector especially employees of private companies. Rests of them are from low-skill and non-skill labor of urban services such as street vendors, taxi drivers and transients. One of the notable finding is only one tenant is government servant.

About marital status, 67 respondents or $54 \%$ are single and rests are married. Generally, majority of families merely have one or two children that average family size of informal rental is distinctively smaller than the national family size (4.4 persons per household). In contrast with household formation, while $75 \%$ of CRR's tenants are single, $75 \%$ of SRR are living with family. $26 \%$ of respondents of SRR are couple without children, $30 \%$ have one child and $13 \%$ have two children.

From monthly disposable income point of view, majority of tenants are low and mid-income as 44\% (Below 300,000 MMK equivalence $225 \mathrm{USD} /$ month), $31 \%$ (Between 300,000 to 500,000 MMK equivalence 225 - $370 \mathrm{USD} / \mathrm{month}$ ) and rests of them (above 370 USD/month). Rental fees vary from 15 to 60 USD depend on size, quality and basic services. About basic services, two-third of tenants doesn't need to pay another charges for electricity and water supply, one-third must be incurred other charges exclusively. Although $30 \%$ of respondents cannot save their income, others usually save 40 to 120 USD per month and round about $60 \%$ of respondents always remit to family from their native.

\subsection{Housing Condition of SRR and CRR Informal Rental Housing}

$97 \%$ of respondent does not owned a house and only 4 respondents have a house owned by their parents or themselves in Yangon who lives in informal rental because of adjacent workplace. As searching information about informal rental, $82 \%$ of respondents have got information from friends and themselves, and only 11 tenants used through the brokers. On the other hand, online social media is very popular in social interaction of current Yangon, only 2 respondents applied to get information through online because of informality.

Although this business is informal from legal point of view, majority of buildings are permanent as $90 \%$ of buildings and only $10 \%$ is substandard quality. Regarding floor area, thumb rule for habitable floor area is 100 square feet $(9.29$ square meters) per person (450 square feet equivalent 41.8 square meters per household); all of SRR and CRR are small than 200 square feet (18.58 square meters) and $70 \%$ of floor area for tenant are equal or less than 100 feet (9.29 square meters). One of the obnoxious findings is that floor areas of CRR are very narrow between 22 square feet (2.04 square meters) to 40 square feet (3.71 square meters). All rental rooms are without separate bedrooms and only cells; only 7 tenants have the attached bathrooms and $94 \%$ share with other tenants. Similarly, most of toilets are common used; $13 \%$ of respondents shared that 5 
persons per toilet is adequate, and rests of them are extremely unacceptable as 10 persons per toilet in $45 \%, 20$ persons per toilet in $23 \%$, and 30 persons per toilet in $8 \%$.

As the proximity, $43 \%$ of respondents live in walking distance between homes to workplace, $26 \%$ usually use public bus transport and $18 \%$ are provided ferry services by employers. Additionally, daily travelling time is very convenient for most of respondents as $67 \%$ are below 15 minutes and $22 \%$ are below $30 \mathrm{mi}$ nutes. Important places such as schools, markets and clinics are very close in below 15 minutes distance. Like as other international experiences, living in the SRR and CRR are bad conditions as crowded, poor basic services and social discontent, $37 \%$ of respondents are very satisfied and $49 \%$ are satisfied on current living condition rather than living in squatter. Main reasons for the avoidance of squatter living are the worsening condition (48\%) and the anxiety on breach of law (46\%).

Majority of landlord are absentee landlords especially all of SRR's owners and only 10 CRR's owners lived together with their tenants. Disputes among landlord-tenant relationship are rare case and a few disputes between tenants can be occurred because of a lot of noise. Moreover, most of the tenants especially CRR's tenants are usually out in the day-time and they use the room only for sleeping in the night. Changing-house frequently is not favored among the informal tenants; $40 \%$ of respondents had only two times, $31 \%$ had three times, $15 \%$ had four times and rest of them had above five times. Main reasons are change of workplace, raise of rental fee and betterment of new place.

\subsection{Influencing Factors for the Growth of Informal Rental Housing}

As other prime cities of the third world, demand is the key factor of the growth of informal rental with scarce land of opportunity for squatting, affordability, and location for transport and other facilities. Moreover, negligence of local authorities is pushing the growth of informality. According to the results of ground survey in this research, the findings point out that most of tenants intended to live in informal rental with two fundamental aspects as the affordability and the proximity. Originally, main root causes of the growth of informal rental in Yangon are intertwined between the accelerated urban growth by internal migration and the dichotomy of the urban population growth and urban poverty.

Moreover, saturation of ubiquitous squatter pockets can fuel to increase of informal rental practices. Questionnaire results spotlighted on this factor as 117 out of 124 respondents deny living in squatters with many reasons and KI result mentioned current occupants aggressively deny accepting the newcomers in their squatter community. As a notable fact, notorious traffic congestion and unreliable public transport push forward the increase of CRR because new squatter spot of periphery of the city cannot attract new migrants especially worker class for urban services. 
As the proximity, two-third of respondents recommended that the proximity of workplace, the accessibility of urban amenities and the closer with relatives and friends are the most important factors for choosing current location. Therefore, workers from industrial zones prefer to live in SRRs of Hlinethaya and Shwepyitha Townships such as new industrial satellite towns and employees from services sector more prefer CRRs of inner city such as Lanmadaw and Kamayut Townships. Other important factors for living informal rental are cheap rental fee and low living cost as the aspect of affability. Moreover, living in informal rental is safer than being evicted while living in squatter.

As the unaffordability, current formal housing market cannot fulfil the unmet demand of mid and low-income group because it is poor functioning and distorted market with fragile key players of government, financial institutions and private house-builders. While the half of the respondents regretfully gave up being a homeowner, the half has a dream to be homeowner in future. Their affordability of buying a house is the price bracket between 10 to 15 MMK (7500 11,000 USD) which is not targeted market segment by private sector in Yangon because of rocket land price. Moreover, their education level, job status and current income are still below the eligibility of regular housing mortgage from the banking sector.

Another indirect influence for the growth of informal rental is the failure of private formal rental housing. Private formal rental practices were very popular under British colony era; it was gradually diminished under Urban Rent Control Act and Government's policy during Parliament Democracy era (1948-1962) and finally disappeared under Socialism (1962-1988). Beyond Socialist era, no governments intervene on the private formal rental; it has never become the lucrative and attractive business with many constraints especially legal constraints.

\section{Conclusions and Recommendations}

In Myanmar, urban Agenda including urban housing has been ignored by the successive governments except Parliament Democracy Regime (1948-1962) and rental housing is neglected by policy makers since independence in 1948. Although issues related rental housing (either formal or informal) are out of the eyes of authorities, it has been gradually grown to be high demand with the dichotomy between the urban population growth and the urban poverty in late $20^{\text {th }}$ and early $21^{\text {st }}$ Century of Yangon.

Moreover, if government does not tackle operative actions seriously on housing agenda, unprecedented urbanization rate of Yangon can surge not only the squatter formation and expansion, but also the growth of informal rental housing. According to the 2014 Myanmar Population and Housing Census, with aspects to urban housing, roughly a quarter of housing stock is only standard, the remaining half is substandard and rest of them is temporary housing such as huts in Yangon. On the other hand, round about half million was squatter population in 2014 and tenants of informal rental could not guess definitely due to 
the lack of reliable data which could be roughly between the half to two-third of squatter population.

Among the three fundamental aspects related informal rental in theory, the proximity and the affordability are more concerned in Yangon context. Generally five types of informal rental are prevalent all over the Global South; two types as Multi-storeys Single-Roomed Rental (SRR) and Cell-Rental Room (CRR) which are more considerable types in Yangon. The proximity of the workplace, the urban services and amenities, and the relatives and friends can boost these SRR and CRR practices. Furthermore, a cheap rental fee, low living cost and unaffordability of buying a house which can push and pull the growth of informal rental with reference to affordability. Although condition of SRR and CRR is inadequate for living that is better than squatter living. Nonetheless, the expansion of squatter and the growth of informal rental are contrary as head and tail of coin being vice-versa for residential solution of urban poor.

There are three fundamental solutions for the informal rental generally as to encourage housing ownership, to promote formal rental housing (public or private rental), and to upgrade informal rental housing. As Myanmar being the LDC country, government should consider to cope with all possible solutions as saying as "one size does not fit all". While encouraging housing ownership and promoting formal rental can be mid-term or long-term plan because of the need for huge capital and nature of business environment, the upgrading informal rental can reach directly to the aim as uplift of quality of life of tenants in short-term. This study focuses only the typologies of current informal rental of Yangon, further research should be recommended on strategic and operative solutions for reducing the informal rental housing and promoting the formal rental in Yangon, Myanmar.

\section{Conflicts of Interest}

The author declares no conflicts of interest regarding the publication of this paper.

\section{References}

Asian Development Bank (ADB) (2019). Financing Affordable Housing in Yangon. Yangon: Asian Development Bank

Amis, P. (1984). Squatter or Tenants: The Commercialization of Unauthorized Housing in Nairobi. World Development, 12, 87-96. https://doi.org/10.1016/0305-750X(84)90037-8

Anyamba, T. J. C. (2005). Nairobi's Informal Modernism. Oslo: Old School of Architecture and Design.

Ballesteros, M. M. (2004). Rental Housing for Urban Low-Income Households in the Philippines. PIDS Discussion Paper Series, No. 2004-47, Makati City: Philippine Institute for Development Studies.

Carey, S. (2009). Investigation into the Proliferation of Low-Income Private Rental Housing Supply and the Development of Recommendations Concerning Appropriate Interven- 
tions/Responses. Johannesburg: The Social Housing Foundation and Urban Landmark.

Chaturvedi, M. (2015). Indian Migrants in Myanmar: Emerging Trends and Challenges. New Delhi: Indian Center for Migration Ministry of Oversea Indian Affairs.

Desai, R., \& Mahadevia, D. (2014). Diversity and Dynamics of Informal Rental Housing in a Mid-Sized City in India. Environment and Urbanization ASIA, 5, 285-301. https://doi.org/10.1177\%2F0975425315577173

DUHD (2012). Policy paper for National Comprehensive Development Plan. Nay Pyi Taw: Department of Urban and Housing Development, Ministry of Construction.

DoP (2015). The 2014 Myanmar Population and Housing Census. Nay Pyi Taw: Ministry of Immigration and Population.

GAD (2019). Internal Report for Squatter Registration. Yangon: General Administration Department, Ministry of Home Affairs.

Gilbert, A. Mabin, A. McCarthy, M., \& Watson, V. (1997). Low-Income Rental Housing: Are South African Cities Different? Environment and Urbanization, 9, 133-148. https://doi.org/10.1177\%2F095624789700900111

Gilbert, (2015). Rental Housing: The International Experience. Habitat International, 54, 173-181. https://doi.org/10.1016/j.habitatint.2015.11.025

Gokhale, S. (2016). Landlord and Tenant Profiles and Informal Rental Arrangements: The Case of Mumbai, India. Master Thesis, Rotterdam: Institute for Housing and Urban Development Studies.

Gulyani, S. (2008). Slum Real Estate: The Low-Quality High Price Puzzle in Nairobi's Slum Rental Market and Its Implications for Theory and Practice. World Development, 36, 1916-1937. https://doi.org/10.1016/j.worlddev.2008.02.010

Housing Department (HD) (1989). Report for Regulations and Procedures Related the Urban Rent Control Act (1960) and Disputes between Landlord and Tenant (Myanmar Version). Rangoon: Housing Department.

Ikhlas, I., \& Shiki, K. (2020). The Lack of Childcare as a Housing Problem: Evaluating the Role of Rusunawa Public Rental Housing as Transitional Housing for Low-Income Families in Batam City, Indonesia. Journal of Regional Information and Development, 9, 82-93.

Kyaing, K. (2014). Urban Land Use Pattern and Residential Land in Yangon. Yangon: Yangon Institute of Economics

Kumar, A. (2016). India's Residential Rental Housing. Economic \& Political Weekly, 51, 112-120.

Lemanski, C. (2009). Augmented Informality: South Africa's Backyard Dwellings as a By-Product of Formal Housing Policy. Habitat International, 33, 472-484. https://doi.org/10.1016/j.habitatint.2009.03.002

London Scholl of Economic (LSE) (2018). Assessing the Evidence on Rent Control from International Perspective. London: London Scholl of Economic.

Matsebula, B. M. (2012). Factor Influencing the Growth of Informal Rental Housing in Swaziland: The Case of Matsapha Peri-Urban Areas. Master Thesis. Johannesburg: University of Witwatersrand.

Myanmar National Building Code (MNBC) (2020). Myanmar National Building Code2020. Nay Pyi Taw: Ministry of Construction, Myanmar.

Mwangi, I. K. (1997). The Nature of Rental Housing in Kenya. Environment and Urbanization, 9, 141-160. https://doi.org/10.1177\%2F095624789700900205 
Naik, M. (2015). Informal Rental Housing Typologies and Experiences of Low-Income Migrant Renters in Gurgaon, India. Environment and Urban Asia, 6, 154-175. https://doi.org/10.1177\%2F0975425315591425

Naing, M., \& Nitivattananon, V. (2020a). Analysis of the Housing Market with the Roles of Private House-Builders on the Middle-Income Group Segment in Yangon, Myanmar. Journal of Construction in Developing Countries, 25, 83-108. https://doi.org/10.21315/jcdc2020.25.1.5

Naing, M., \& Nitivattananon, V. (2020b). Comparison of Issues and Countermeasures among Previous and Current Squatter Formations in Yangon, Myanmar. Urban Current Studies, 8, 396-416. https://doi.org/10.4236/cus.2020.83022

O'Connor, R. (2020). Urban Migration in Myanmar: An Analysis of Migration Patterns and Migrant Well-Being, City Life Survey Discussion Paper. Yangon: The Asia Foundation

Pearn, B. R. (1939). A History of Rangoon (pp. 229). Rangoon (Yangon): American Baptist Mission Press.

Peppercorn, I. G., \& Taffin, C. (2013). Rental Housing: Lessons from International Experience and Policies for Emerging Markets. Washington DC: World Bank Group. https://doi.org/10.1596/978-0-8213-9655-1

Scheba, A., \& Turok, I. (2020). Informal Rental Housing in the South: Dynamic but Neglected. Environment and Urbanization, 32, 109-132. https://doi.org/10.1177\%2F0956247819895958

Shapurjee, Y., \& Charlton, S. (2013). Transforming South Africa's Low-Income Housing Projects through Backyard Dwellings: Intersections with Households and the State in Alexandra, Johannesburg. Journal of Housing and the Built Environment, 28, 653-666. https://doi.org/10.1007/s10901-013-9350-9

Turner, B., \& Malpezzi, S. (2003). A Review of Empirical Evidence on the Costs and Benefits of Rent Control. Swedish Economic Policy Review, 10, 11-56.

UN-Habitat (2003). Rental Housing: An Essential Option for the Urban Poor in Developing Countries. Nairobi: UN-Habitat.

UN-Habitat (2008). Housing the Poor in Asian Cities, Quick Guide 7; Rental Housing: A Much Neglected Housing Option for the Poor. Bangkok: United Nations Economic and Social Commission for Asia and the Pacific.

UN-Habitat Myanmar (2018). Yangon Informal Settlements-Resettlement Progrmamme (YIS-RP) Survey II Report. Yangon: UN-Habitat, Myanmar.

Willis, J. W. (1950). Short History of Rent Control Laws. Cornell Law Review, 36, 54-92.

Watson, V., \& McCarthy, M. (1997). Rental Housing Policy and the Role of the Household Rental Sector: Evidence from South Africa. Habitat International, 22, 49-56. https://doi.org/10.1016/S0197-3975(97)00023-4

Watson, V. (2009). Strategic Literature Assessment for Informal Rental Research Project: Report to the Social Housing Foundation. School of Architecture, Planning and Geomatics. Cape Town: University of Cape Town. 